\title{
Community Based Organisations in Environment Conservation Endeavours in Rwanda
}

\author{
Dr. Isaboke Peter Kennedy Nyataya*, PhD \\ Senior Lecturer Cum Director of Academic Affairs and Quality Assurance, University of Tourism, Technology \\ and Business Studies-Rwanda
}

*Corresponding Author: Dr. Isaboke Peter Kennedy Nyataya, Senior Lecturer Cum Director of Academic Affairs and Quality Assurance, University of Tourism, Technology and Business StudiesRwanda

\begin{abstract}
The present study was conducted with a view to understanding the contribution of community based organisations towards conservation of environment in Rwanda, with Sabyinyo Community Livelihood Association (SACOLA) of Kinigi Sector, Musanze District. Descriptive research cum case study research designs were adopted for the study. The target population was 800 comprising SACOLA community members. The representative sample size was represented by 10\% (80) of the target population and purposive sampling technique was used in selecting the respondents for the study. Primary data was collected from the respondents through the use of questionnaires whereas secondary data was collected through the use of content analysis method. The obtained data was presented in forms of tables, figures, graphs, pie charts, percentages, and averages and analysed through the use of SPSS - Version 21. Findings of the study indicate that SACOLA conducted moblisation activities with the aim of sensitising, training and educating communities in the selected area of the present study and its environs on the importance of environment conservation besides creating awareness regarding causes that were related to the mission and vision of the organisation. SACOLA help in the implementation of environment conservation practices by ensuring that natural resources in the area were well utilised, firms adhered to environment conservation measures and through partnerships with other governmental conservation agencies. SACOLAs projects were well planned and executed. There were negative correlations between SACOLA's roles: community mobilisation efforts; implementation of environmental conservation practices and monitoring and evaluation and environmental conservation indicators in Kinigi Sector. The study recommends that SACOLA should find appropriate and applicable ways of ensuring socioeconomic growth among its member and directed its energy towards the formation of self-help groups which could then help in adding value to the endeavours directed towards conservation of environment
\end{abstract}

Keywords: Community-Based Organisation, Environment, Conservation, Endeavours.

\section{INTRODUCTION}

One of the key challenges facing humankind in the contemporary society is the manner in which natural resource conservation can be made to go hand in hand with any given community's development. Inspite of their long historical interaction with ecosystems, neighbouring communities have contributed to endangering their equilibrium through the incompatibility between conservation and their productive practices as Hernandez observed (2013). In the 1970s, conservationists realised that many conservation efforts around the world were failing in their mission of wildlife conservation (Hackel, 2009).Hence, claimed the said the failure was due to lack of support for conservation by local community. Therefore, Community conservation was then initiated as an approach to be used with a view to gaining communities' support for conservation efforts. Ecological preservation is a basic practice in securing the earth, an individual, organisational or government levels, for the advantage of the common habitat and (or) people (Otto et al., 2013). Environmental conservation is important because natural resources can easily become depleted for example forests and plants as noted by Ninan(2012). Besides, there are other benefits associated with environmental conservation that include preventing global warming which is connected to ozone-depleting emissions among other benefits such as management of water catchment areas. Environmental conservation also helps in guarding food supplies and plummeting air temperature and toxins from the environment. In addition, the increase in population over the time, the environment has voluntarily been influenced by the 
human actions such deforestation and pollution, among others. This has necessitated for the global concerns in the conservation of the environment under which the environmental management organisation and conservation policies have been formulated as Otto et al.(2013),noted. Environmental conservation is an activity that is determined to preserve environmental resources damaged by human activities. Besides, it aims at guaranteeing that the biological system is maintained and kept up for fair-minded use by future human generations and furthermore sustain the reliability of the environment as the end in itself by taking into contemplations moral, monetary and ecological factors as observed by Van der Duim et al (2014). The said role is played by not only by governments and individuals on their own capacities but also by other bodies such as community based organisations. Community based organisations (CBOs) are nonprofit groups developed to address community needs such as create employment by providing work opportunities, improving (Otto et al., 2013). Their concentration is to assemble fairness crosswise over society in all streams healthcare, environment, nature of training and access to innovation, to name but a few (Van der Duim, Lamers, and Van Wijk, 2014). Community based organisations more often than not have been involved in activities whose themes are the provision of humanitarian services, ecological conservation efforts beside the revitalisation and promotion of safety in urban centers. The use of CBOs in environmental conservation endeavours, the co-management or mutual management of a protected area is one of the tactics used in community-based conservation as Ninan (2012) pinpoints. Co-management consolidates local community groups' customary learning of the environment with the present-day logical information provided by researcher that has prompted the expanded biodiversity and better administration of the secured region. World all over, CBOs have been seen promoting the conservation of forests and rivers in different countries They have helped create global awareness on conservation of environment by advocating for reduction of pollution of environment and particularly in the developed countries such as the United Kingdom where vibrant CBOs exist (Otto et al.,2013). In Samoa, for instance, Vaiusu village mangrove had been the most degraded mangrove area as Boon (2001) observed. However, with the affirm mandate of a community based organisation, the area was restored. Australia also, through local CBOs managed to plant three million trees by the year 2010, thanks to an initiative Called "Let's Go Green" campaign that aimed to restore the deteriorating environment caused by human encroachment (Devkota, 2010). In Africa, too, research studies have shown that CBOs have a pivotal role in generating knowledge on environment conservation and hence, formulated systems with a view to preserving and maintaining their common assets. CBOs have been able to identify conservation challenges and dealt with them through locallevel experimentation, innovation and trade of data with different social orders. More than half of the tree cover in South Africa has been attributed to CBOs' efforts, thanks to the Vaal Experimental Conservancy which was at the forefront on tree planting exercise as noted by Arthington (2012). In Kenya, environmental conservation has not been effected wholly due to focus on other sections of the conservation efforts while other projects have been left unattended. Several environmental conservation agencies have been formulated to advocate for tree planting such as the Green Belt Movement and the Mount Kenya biodiversity which was started by a group of youths who were conscious about conserving their environment, noted, Nivola (2008). In Rwanda, as observed at the Volcanoes National Park in 2005, it is pointed out that the primary aim for incorporating community conservation in the park management was to increase support for the park and wildlife conservation from the surrounding communities (ORTPN, 2005). However, it is seen that ever since the establishment of Rwandan Office for Tourism and National Parks (ORTPN) in 1974, there has never been any structure to exhibit that environmental protection can add value towards the development of the local population. Hence, in the same vein, it has been noted that there has been lack of mechanisms to resolve clashes such as those subsequent from harm caused by wild animals. Before the establishment of community conservation department in the Office Rwandais du Tourisme et des Parcs Nationaux (ORTPN) and at the Volcanoes National Park (PNV) level, the environmental educational activities by the park staff were supported by community initiatives implemented by different conservation Non-Governmental Organisations. Community-Based Organisations have been reported to play a noteworthy part in the preservation of National Parks in Rwanda. SACOLA (Sabyinyo Community Livelihood Association), is one of the notable non-profit making affiliations in Rwanda which was established in 2004 by the local inhabitants of the former Kinigi District encompassing the Volcanoes National Park with the help of the Rwanda Office of Tourism and National Parks (ORTPN), the International Gorillas Conservation Programme (IGCP), the administration experts of the Sectors of the then Kinigi District and now Kinigi Sector of Musanze 
District. The affiliation began with 34 founder individuals representing the communities in Sectors Surrounding the Volcanoes National Park.

SACOLA was created with a view to protecting the Volcanoes National Park in order to Facilitate the aforementioned communities' development activities that could help enhance their livelihood at the same preventing and controlling the possible dangers posed in conserving the Volcanoes National Park in general and preserving gorillas in particular. The $\mathrm{CBO}$ in picture continue playing a pivotal role in conserving the environment in the area and hence, calls for maximum support from all the relevant and willing agencies in order to be able carry out its functions efficiently and effectively as well.

It is against the afore mention backdrop the present researcher decided to conduct the present research with a view to understanding how the selected $\mathrm{CBO}$ has and is able to facilitate the process of conservation of environment in the area covered under the study.

\subsection{Statement of the Problem}

Environment conservation is not only done with a view to ensuring the survival of the ecosystem but also to gaining benefits associated with it. Hence, It is everyone's business to see to it that the environment is timely and adequately conserved. It is interesting to note that till today, environmental conservation is viewed as serious challenge in Rwanda just like in other countries in the developing world even despite the numerous efforts Government is making directed towards ensuring the sustainability of natural resources including forest cover. It has been observed that since the establishment of the Volcanoes National Park (VNP) in 1925, it has been noted to have lost nearly half of its original size. It is also noteworthy stating that Community based organisations focusing on environmental conservation have been operating in Rwanda for a considerable period of time. Rutagarama et al. (2008) notes that community conservation organisations in country have been in existence since 2003. SACOLA, one of them was launched in 2004 with its membership drawn from all the cells of Kinigi Sector with its main mission being to conserve the environment around the VNP. it is worth mentioning that the key successes and contributions SACOLA in the area, have not been adequately captured by the available record of research studies conducted so far on the same. Besides, it is observed that community social organisation and educating the public on human rights are the main activities undertaken by a number of community based organisations in Rwanda and not much attention has been directed towards environment conservation as such, hence, resulting into the birth and existence of numerous challenges posed to the country due to inadequate or lack of environment management. Hence, it is against the aforementioned background that the present study was conducted with a view to highlighting the key role Sabyinyo community livelihood association has been and is playing directed towards environmental conservation in area

\subsection{Objective of the Study}

The main objective of the present study was to understand and highlight the contributions made by and the successes attained so far by the Sabyinyo Community Livelihood Association (SACOLA) as one of the success stories of community based organisations whose main activity has been to protect and conserve environment in Kinigi Sector of Musanze District.

\subsection{Significance of the Study}

The findings of the present study are likely to benefit directly the communities living in and around Kinigi Sector for they might not only be able to know the importance of SACOLA to the area in particular but also in protecting and conserving the environment in general. Besides, the acquisition of knowledge on to deal efficiently and effectively with problems and challenges which come as result of failure or inadequate know- how on how to manage the environment. The environmental conservation agencies and other stakeholders of the sector in the country might the findings of the present study to be of some help to them in regards to environmental conservation success stories taking SACOLA as good example and model proper protection and management of environment through community mobilisation, advocacy and participation, besides, the implementation of the established laws and policies directed towards conserving environment. The findings, too, might serve as useful tool to be used by stakeholders and other interested parties committed to protecting and conserving the environment in the country and beyond. The Government of Rwanda, NGOs and friends of environment protection and conservation may also benefit from the findings of the study especially in understanding the place and the potentials CBOs in general have in mobilising 
communities around the issues of environment conservation, taking SACOLA as success story that can be emulated besides serving as role model to the country and to other countries in the world.

\subsection{Scope}

The study was conducted with a view to understanding how SACOLA, over the years, has been able to devote and direct its energies towards senstising, educating, advocating for and mobilising the coummunities in Kinigi Sector and its environs on the essence of conserving their environment in general and in conserving the Volcanoes National Park in particular.

\section{LITERATURE REVIEW}

\subsection{Community Based Organisations}

For decades now, community-based organisations (CBOs) have been viewed as active initiators and participants in all-round development activities in many a country in of the world. As Van der Duim et al. (2014) rightly noted, CBOs are the face of community empowerment through the benefit of its democratic procedures, expanding on the social capital and dependence on community efforts. Further adds that numerous advancement ventures have made the CBOs develop as a 'models' natural in the task standards, frameworks and procedures. In many a time, CBOs have been seen shaping, developing and stabilising communities. However, in the absence of funding support, CBOs have been meeting with challenges in managing their capacities and hence, this hindering their ability to thrive. Creating and financing CBOs is a venture that pays its profits in the medium and long terms as well.

\subsubsection{Community-Based Organisations' Role}

CBOs frequently assume remarkable role that cannot be filled either by government office staff or by local landowners and businesses all alone. These roles are regularly significant to guaranteeing that conservation financing discovers its approach, achieves appealing ecological, monetary and social outcomes (Ibid). Among the important roles played CBOs is monitoring and evaluation of conservation activities within assigned areas. Monitoring and evaluation are dissimilar practices devoted to the appraisal of community-based associations and overall execution. Monitoring is a methodical and long-haul process that assembles data with respect to the advances made by an actualised project. Evaluation is time particular and performed to establish whether a project has achieved its objectives and conveyed what is anticipated in line with its unique arrangement.

Monitoring and evaluation are vital tools in carrying out assessments that aim at determining whether CBO projects have achieved the set targets or not. Besides, the processes not only enable an organisation to evaluate the need to make any strategic needs and make informed decisions but also in seeking funding. Community-based organisations more often than not offer support to collaborative institutions that bring together diverse opinions, interests and are anchored towards the promotion of common social, environmental and economical efforts (Ibid).In addition, CBOs support and link local communities with government agencies, more so in situations where mistrust and hostility exists. Ecological roles of the CBOs include coordinating local and regional partners and stakeholders with the aim of planning, designing and implementing conservation strategies, evaluating and monitoring the effectiveness of conservation strategies, and making information and policies regarding conservation efforts available to local communities and involved stakeholders. Community-based organisations also play technical as well as financial role which encompass availing the required monetary resources and experts to help local groups to understand the conservation concept and work in unison with other state and private stakeholders in observing conservation programmes and activities (Van Wijk, 2014).

\subsection{Conservation of Environment}

The greater part of the world's resources are particularly vulnerable on the grounds that they are affected by human activities across numerous nations. Hence, numerous endeavours have been made by various nations with a view to creating understanding that are earmarked by different governments to anticipate harm or deal with the effects of human action on natural resources as Allaby and Park (2013) observed.

Studies concerning environmental protection have been focused on the contributions of government on environmental preservation through legislation. While this is the case, (Büscher, Dressler and Fletcher (2014) content that the role of protecting the environment is broadly seen as the responsibility of the population as opposed to that of the government. Basically, assessment 
concerning the influence of environmental conservation efforts involves numerous stakeholders including local groups, environmental groups, and community representatives. Progressively, the decision regarding environmental conservation process is evolving and in a way reflecting the collective efforts of stakeholders.

As Allaby and Park (2013) noted, a significant a number of states acknowledge the importance of natural assurance and universal understanding to yield to one side to dwell in a solid situation. Most of the nations have put in place organisations and associations mandated to protect the environment. It is also significant to acknowledge the existence of global ecological assurance associations, for example, the United Nations Environmental Programme (UNEP). While ecological insurance does not just mean the obligation of government organisations, the general conception that puts more emphasis on the importance of government agencies in inaugurating and upholding fundamental standards that safeguard the environment and its inhabitants (FAO, 2011).

Globally, environment conservation has been an issue of concern in many nations. This is as a result of increase in population and also human activities which are threat to the environment (Büscher et al.,2014).China, first instituted its formal environmental protection in 1972 through the United Nations Conference on Human Environment that was held in Stockholm, Sweden (Zhang and Wen, 2008). It is this conference that prompted the Chinese government to institute environmental protection agencies and also oversaw controls on industrial waste, making it the first among other developing nations to implement a sustainable development strategy with environmental conservation being one of its main agendas (Kersten, Mikolajuk and Yeh, 2010). Environmental conservation has also been an issue of concern to many developing nations particularly in Africa for quite some time now. In Tanzania, environmental protection commenced during the in the period of the German control of East Africa (1884-1919) when the provisions safeguarding laws for the affirmation of diversion and timberlands were requested, whereby restrictions were put upon regular indigenous activities, for instance, chasing, the gathering of kindling and cattle crunching (FAO, 2011). In 2008, Serengeti was formally settled as the principal national stop for wild creatures in East Africa. Since 1983, there has been an all the wider accomplishing pushes to supervise biological protection issues at a national level through the establishment of the National Environment Council (NEMC) and the progression of a natural demonstration.

\subsection{Community Based Organisations and Environment Conservation}

It is hard to understand community-based conservation concept without having a basic understanding of the interactions between the internal and external factors that initiate conservation, which is referred to as drivers and motivations, respectively (Souto et al., 2014). Conservation drivers are defined by circumstantial situations and assorted organisational practices, occurring both globally and locally, providing local communities incentives or sanctions that push them to participate in conservation practices (ESPA-AA, 2008). Incentives are guided by individual or group targets that incite human behaviors towards a common good, which in this case include environmental conservation (Ryan and Deci, 2010).The many-sided quality of such associations depends on the way that activating occasions and the social-natural setting impact individuals' individual and aggregate ecological conduct.

The ability of local people to engage in environmental conservation and management practices can be linked to situational factors, which are external to communities such as conflicts and disasters and environmental degradation (Seixas and Davy, 2008). National interventions have also been identifies as vital drivers to these initiatives (ESPA-AA, 2008). Motivator drivers can as well encompass monetary incentives and policy measures that aim at enhancing conservation efforts within communities. For example, new market opportunities arising from conservation efforts offer communities with platforms for economic activities and at the same time offer them ecosystem returns while state regulatory policies supporting sustainable management of resources enhance biodiversity conservation (Seixas and Davy, 2008). The integration of local communities and external institutions in community-based conservation efforts results into shared visions between different stakeholders involves and this they share a common vision and mission concerning the improvement of natural resource and management of these resources to achieve maximum benefits of the local populations (Schwartzman and Zimmerman, 2015). Robust associations have the potential to spur and promote environmental conservation by underlining the role of local leadership and providing necessary financial and capacity building support to local communities (Berkes and Seixas, 2004; 
Seixas and Davy, 2008; Shukla and Sinclair, 2010).The inspiration to have local populations participates in systematised preservation endeavors may likewise come about because of inborn inspiration as opposed to monetary incentives. The said could be characterised by the collective sense of independence that has the ability to drive people with access to natural resources to make decisions concerning land and natural resources control that gang up against threats from the outside as well as ensure that their resources are conserved for future generations (Berkes, 2009; Kosoy, Corbera, and Brown, 2008; Robinson and Sasu 2013). Whereas the motivation for keeping up customary network based administration and preservation efforts stems from the collective interest in land and resource ownership, local communities can be driven by other people's concerns (DeCaro and Stokes 2008). For istance, conservations efforts to manage local forests by the Totonac community in Mexico are based upon the ability of the state to obtain medicine and construction material among other assets that forests provide to mankind (Toledo, Ortiz-Espejel, Cortés, Moguel and Ordoñez, 2013). Cultural reasons may also influence the capacity of nearby networks to take part in conventional neighbourhood asset administration practices. Besides, as Méndez-López (2014) suggested, local communities often participate in conservation and as an obligation towards collective customary laws. In India, for instance, people are bound by taboos and spirituality to keep up standard woods administration hones in holy woodlands (Ormsby and Bhagwat, 2010).

\subsection{Community-Based Conservation}

The past three decades saw the promotion of community-based conservation (CBC) as a tool for development. The fundamental idea behind $\mathrm{CBC}$ has been to empower community members and their respective institutions to protect wildlife that overflows in private and communal lands (Noe and Kangalawe, 2015). Besides, it was expected that conservation could result into economic prosperity for the participating communities through different ventures such as tourism and regulated wildlife harvesting. In many countries in the South and Eastern Africa, community-based conservation schemes have sort to set aside land for wildlife while giving villages control over revenues and resources on those lands (Nelson and Agrawaal, 2008).The approach of community conservation came as a counter-narrative to the fortress approach and has two elements: to allow people in and around protected regions to take interest in the management of preservation resources and the linkage of conservation destinations to local improvement needs. Other than the way that community conservation provided an innovation with regards to the need of conservation, it also fitted the discourse of development and foreign aid policy (Hulme and Murphree, 2010). The responsibility for biodiversity and wildlife makes a fascinating story. Before the nineteenth century, hallowed forests and old imperial timberlands gave nature security in some routes practically identical to preservation in contemporary protected zones (Mulder and Coppolillo, 2015). Roe et al (2010) linked the latenineteenth century thought to the possibility of national parks, that individuals and untamed animals are in struggle, and that natural regions ought to be put aside only for non-destructive intentions was a noteworthy and so was the supposition of responsibility for wildlife resources by the state, a thought that has come to rule preservation policies around the globe. The establishment of preservation policies could be a step but the ability to enforce the policy is something else. Indigenous resourcebased communities have often confronted claims by the state to own over resources they believe are in their dominion as noted by Brechin et al., 2013). Issues over community environmental conservation are rather complex just as issues concerned with community management (Berkes, 2014). The inquiry surrounding the ability of community-based managed in supporting conservation and whether communities can be entrusted with conservation have been hotly debated by numerous stakeholders including environmental specialists and government agencies (Holt, 2015). However, the answer to these hard, yet, important areas of interest depends on the defining of conservation by parties involved (Berkes and Turner, 2016). Community-based preservation as judicious utilisers, in light of the fact that livelihoods rely upon the long haul supportability of nearby assets, almost certainly has a long history. Be that as it may, community-based protection as an idea and panacea is generally new and appears to have been created in response to the panacea of state-managed conservation efforts (Murphree, 2012).

Salafsky and Wollenberg (2010) and Brown (2012) identified distinct phases of community- based conservation. Salafsky and Wollenberg noted the inception of community-based conservation with the 1980s funding of the Integrated Conservation and Development Projects (ICDPs) by the Word Bank (WB) and the Asian Development Bank (ADB).Huge numbers of these undertakings depended on a 
protected-area idea and which objective was to increase benefits through elective work exercises as an approach to decrease the danger to protection from local people. Community-based preservation of the 1990s advanced by attempting to build up immediate linkages amongst protection which would benefit local communities. Such a connection amongst biodiversity and livelihood shuts the circle and turns into the main impetus prompting preservation by building up an immediate motivator for local people to ensure biodiversity in the long haul Salafsky and Wollenberg, pointed out.

The afore mentioned community-based approaches were developed as response to the catastrophes of state-run conservation efforts, and were more inclusive and penetrated the local needs of communities. Before long ago, the old account of 'fortification protection' was to a great extent dislodged by the counter story of change through network preservation and sustainable use (Murphee,2012).Notwithstanding, community-based preservation as a strategic plan undermined threated to become a panac

\subsection{Community Mobilisation and Environment Conservation}

Shrestha (2013) conducted a study on community participation and mobilisation in wetland conservation in Nepal which finding show that community participation and mobilisation played a significant part in the development of capacity with respect to the management and use of resources economically. Van der Ploeg et al (2011) surveyed the viability of ecological education in mobilising public support for Philippine crocodile preservation which found that the campaign was successful in raising awareness on the same and transforming the public's attitudes towards crocodile conservation in the area. The local community living in close proximity to the crocodiles were mobilised and informed on the importance of the species which was to be legally protected as conservation measures in support of environmental conservation. As a result, crocodiles were no longer killed purposively. The study concluded that community mobilisation and environmental education substantially informed environmental conservation efforts.

\subsection{Environmental Conservation Organisations}

Ruiz-Mallén et al.(2015) conceptualized community-based preservation by investigating trigger occasions and inspirations that instigated local communities to be occupied with reasonable institutional engagements for effective natural resource management and biodiversity protection. The study revealed that incentive-based conservation policies imposed by community based environmental conservation organisations oriented people's actions. Besides, the organisations were found to be instrumental in airing out environmental justice concerns which supported the local people' sense of autonomy and providing insights into the governance of conservation development at the grassroots. Ntuli and Muchapondwa (2015) examined the role of organisations in community wildlife conservation. The examination broke down the relationship amongst organisations collaboration and the connection with participation and accomplishment of biodiversity results. It was observed that uncovered that external authorisation of standards and directions did not really translate into sound ecological outcomes but better results were achieved when discipline was embraced by the local communities. Hence, the researchers, were of the view that communities should have been upheld in a way that advanced the rise of powerful institutions that were carefully fit to suit local needs.

\subsection{Community Based Organisations and Environmental Conservation}

Tangui (2014) conducted a study on role of Community Based Organisations (CBOs) in the conservation of environment in Kenya which results indicated that CBOs played a vital role in promoting environmental conservation, mobilizing the community, implementing environmental conservation practices and monitoring and evaluation conservation practices. A study by Uwimana (2017) on the influence of community based organisations in the preservation of the Volcano National Park found that there was a significant difference between the frequency of visiting the park before and after the CBO interventional activities.

Today, community based organisations have become influential conservation agents especially in the developing world. Substantial number of CBOs have been participating in environmental development and conservation with their own agenda, especially where environment conservation is linked with local communities and the environment. Community based organisations are distinct from other organisations for they not only target conservation but also the social and environmental goals of the local community. The performance of CBOs in conserving environment depends on how well 
these organisations are now able to respond to changes in the environment. Hence, their effectiveness in conservation of the environment is dependent on the management and firm effects in the form of resources and the strategies developed to attain sustainable environment Schwartzman and Zimmerman,2015). Further, it is evident that the interventions brought about by CBOs with the aim of achieving environmental sustainability are effectively transforming communities. The interventions have opened a window for beneficiary participation in new economic activities that preserve national resources by conserving the ecosystem and thus gain in natural resource conservation. In the pursuit to conserve the environment, developments brought about by CBOs who have continued to carry on as a result of the increase of community involvement due the destruction caused the environment through illegal activities such as deforestation. The conservation of the environment is threatened by a number of factors including the stagnation of income generation or monetary challenges of the communities resulting to poaching and lumbering Tangui (2014), observes. Population growth challenges the availability of available land for food production as conservation efforts strive to convert more land into tree plantations. As such, there grows competition and disagreements between conservatives and the population which challenges the ability of CBOs to sustain biodiversity and the conservation of natural areas. However, there are different strategies that CBOs have been adopted so as to achieve their objectives of ensuring environmental conservation and they include promoting environmental practices using income generating activities, community mobilisation, implementation of various conservation practices, and by enhancing monitoring and evaluation of conservation practices. This greatly helps in ensuring effective environment conservation Uwimana (2017), highlighted The study was undertaken with a view to demonstrate the role of community based organisations in conserving the environment, taking SACOLA as the case study.

\section{RESEARCH DESIGN AND METHODS}

Descriptive design cum case study were adopted for the present study.

\subsection{Target Population and Representative Sample Size}

Target population for the research was 800, comprising members of SACOLA 10\% (80) of the target population was scientifically chosen for the study selected as the representative sample size of the study. Purposive and simple random sampling techniques were adopted for the selection of respondents who included the members of the $\mathrm{CBO}$ covered under the study.

\subsection{Sources of Data and Methods of Data Collection}

Data were obtained from both primary sources and secondary sources. Primary data through the use of a questionnaire administered to the selected respondents for the study, whereas, content analysis method served as the source for secondary data

\subsection{Reliability and Validity}

Validity of the method used for collecting data was assured through ensuring that the study remains focused mainly on the content of the range of items covered in the study. Again, the Questions used were pre-tested by administering to the same respondent in order to eliminate the threat of biasness. Reliability was determined through the application of scale reliability test in SPSS (Version 21).

\subsection{Presentation of Data and Methods of Data Analysis}

Data were presented in the form of tables, graphs, figures, pie-charts, frequencies, percentages and averages and analysed through the use of SPSS.

\section{FINDINGS AND DISCUSSION}

The majority (64.79\%) of the respondents was male. This confirms Rwanda's Vision 2030 of aiming to achieve gender equality and inclusion of both genders in social and economic activities. $42.25 \%$ of the respondents belonged to age-group 36-45, 38.03\% of them $26-35,15.49 \%$ over 46 years whereas $4.23 \%$ were below 25 years old. Hence, it was observed that membership of SACOLA was dominated by members who were in their middle age with adequate experience in undertaking economic activities besides being viewed as mature enough to understand the importance of conservation as well as the vision and mission of the aforementioned association. In addition, the age of the respondents' indicated the membership of the association comprises young generation, below 25 years of old which is belied to be energetic and expected to continue actively participating in 
environment conservation efforts for long due to their youthfulness and hence help transform the future generations. Respondents with secondary education formed the majority (59.15\%), bachelor degree holders were $23.94 \%$, (12.68\%) with primary school certificates and $(4.23 \%)$, master's degree holders. It is noteworthy mentioning that respondents were noticed to have clear knowledge and understanding on environmental conservation and role played by CBOs in general and SACOLA in particular towards the efforts directed to environment protection and conservation. The majority (38.03\%) of the respondents were noted to have been members of the association for a period between 6 and10 years, $33.80 \%$ of them $2-5$ years, $15.49 \%$ had been members for 11 and above years whereas $12.68 \%$ were less than 1 year old as members. It was then seen that about $90 \%$ of the respondents had been members of the association at least for a period of 2 years and hence, assumed to be conversant with the activities pertaining to environment conservation. Too, it can be said that SACOLA is known to the community and seen to be meeting the interests of the community.

The study confirmed that SACOLA as community based organisation has been and continue playing active and fundamental role in bringing together members of the community with a view to identifying human degradation activities that are viewed as great threats and challenges to their wellbeing and livelihood as consequences of continued depleting the environment. Besides, it is seen as external agency that has made tremendous efforts towards bringing and ensuring the coming together of community members with a view to sensitising and educating them on how they can protect and conserve their present environment. It was also observed that SACOLA through its advocacy and mobilisations abilities and efforts the community in the area has been enabled to think critically about their environment and joined hands in ensuring its conservation due to the numerous benefits can earned by them and their future generations through it. Significantly noticed was also the fact environmental conservation does not only entail conserving protected areas but also entails the involvement of both local people and important stakeholders such as CBOs as demonstrated by the SACOLA. Further, it was observed that involving the local communities through community based organisations was an effective approach towards ensuring sustainable environment conservation as evidenced by the selected CBO.

It was found that SACOLA was focused educating local communities and awareness creation and mobilised people drawn from different sections of the community with a view to empowering with information on conservation of environment. Noticed also was the existence of self-help groups in the area formed as result of SACOLA's mobilisation efforts directed towards educating and training communities on the importance of environment conservation as well as creating awareness regarding causes that were related to the mission and vision of the organisation. SACOLA was found to be directly involving communities in its activities and therefore, viewed as association comprising communities and owned by communities and meant communities in the area. The association was found to be of great benefit to the people due to its clearly visible developmental initiatives such as construction of hotels in the region that serve as sources of income and employment for the communities. The study brought light the fact that CBOs continue playing an important role in mobilising communities with the aim of achieving community-based conservation visions and missions as noted by Schwartzman and Zimmerman (2015) that the integration of local communities and external institutions in community-based conservation efforts resulted into shared visions between different stakeholders involved and through this they shared a common vision and mission concerning the improvement of natural resources and management of these resources to achieve maximum benefits of the local populations. Sixes and Davy (2008), too, observed that robust associations had the potential to spur and promote environmental conservation by underlining the role of local leadership and provision of the required financial resources and also the offering of capacity building support to local communities. SACOLA was found to be an active participant in the implementation of environment conservation practices by ensuring that natural resources were well utilised, firms adhered to environment conservation measures and through partnerships with other governmental conservation agencies. SACOLA focused on various aspects of conservation including educating local communities and awareness creation. Respondents agreed with the statement SACOLA recruited people from different sections of the community with the aim of empowering them with information regarding the conservation. Respondents agreed with the statement most of the developmental projects supporting the conservation of the environment in the area resulted from SACOLA initiatives. Respondents were undecided with the statement suggesting that there were many self-help groups in the area as a result of SACOLA's activities. 


\section{CONCLUSION}

SACOLA's mobilisation capacities has enabled it achieve its main aim of sensitising, training and educating communities in the area and its environs on the importance of environment conservation. Too, it has ensured that that natural resources in the area of its operation were well utilised, firms adhered to environment conservation measures, and through partnerships with other governmental conservation agencies. SACOLA's projects were well planned and it effectively SACOLA effectively monitored its conservation initiatives. SACOLA serves as one example of the success stories and hence, role model as community based organisation has tremendously done well in its endeavours directed towards environment conservation and its unimaginable numerous fruits for the present communities and their future generations.

\section{RECOMMENDATIONS}

SACOLA should find suitable means of ensuring that the socio economic growth of communities mobilised around the issues of environment conservation. Besides, it should make sure that its monitoring and evaluation reports reach other stakeholders with a view to sharing their contents and feedbacks that can be used to improve their services in the area. SACOLA is dominated by middleaged membership. Hence, the association should finding appropriate and attractive approaches that can be used with a view to pulling the youth towards environment conservation endeavours.

\section{REFERENCES}

[1] Benton, T., and Redclift, M. (2013). Social theory and the global environment. Routledge.

[2] Berkes, F. (2009). Community conserved areas: policy issues in historic and contemporary context. Conservation letters, 2(1).

[3] Berkes, F. (2014). Rethinking community-based conservation. Conservation biology, 18(3),

[4] Berkes, F., and Seixas, C. S. (2004). Lessons from community self-organisation and cross- scale linkages in four Equator Initiative projects.

[5] Berkes, F., and Turner, N. J. (2016). Knowledge, learning and the evolution of conservation practice for social-ecological system resilience.

[6] Boon, J. M. (2001). A socio-economic analysis of mangrove degradation in Samoa. Geographical review of Japan, Series B.

[7] Brosius, P. J., Tsing, A. L., and Zerner, C. (2005). Communities and conservation: histories and politics of community-based natural resource management. Rowman Altamira.

[8] Büscher, B., Dressler, W., and Fletcher, R. (2014). Nature Inc.: environmental conservation in the neoliberal age. University of Arizona Press.

[9] Conrad, C. C., and Hilchey, K. G. (2011). A review of citizen science and community-based environmental monitoring: issues and opportunities. Environmental monitoring and assessment.

[10] DeCaro, D., and Stokes, M. (2008). Social-psychological principles of community-based conservation and conservancy motivation: attaining goals within an autonomy-supportive environment. Conservation Biology.

[11] Devkota, R. R. (2010). Interests and power as drivers of community forestry: a case study of Nepal. Universitätsverlag Göttingen.

[12] Ecosystem Services and Poverty Alleviation Programme, Andes-Amazon (ESPA-AA). (2008). Challenges to managing ecosystems sustainably for poverty alleviation: securing well-being in the Andes/ Amazon. Situation analysis prepared for the ESPA Program. Amazon Initiative Consortium, Belém, Brazil.

[13] FAO. (2011). State of the World Forests Rome

[14] Hackel, D. J. (2009). Community conservation and the future of Africa"s wildlife. Conservation Biology.

[15] Henriques, J, Hollway, W, Urwin, C. (1984) Changing the Subject: Psychology, Social Regulation and Subjectivity. London: Methuen and Co. Ltd.

[16] Hernandez, J. C. C. (2013). Community-based conservation: participatory conservation in buffer zone communities in the natural protected areas of Chiapas, Mexico. Nature Conservancy.

[17] Holt, F. L. (2015). The Catch-22 of conservation: indigenous peoples, biologists and cultural change. Human Ecology.

[18] Hulme, D., and Murphree, M. (2010). Community conservation in Africa: An introduction. African wildlife and livelihoods: The promise and performance of community Conservation.

[19] Kosoy, N., Corbera, E., and Brown, K. (2008). Participation in payments for ecosystem services: case studies from the Lacandon rainforest, Mexico. 
[20] Mugenda, M. O., and Mugenda, G. A. (2003). Research Methods Quantitative and Qualitative Approaches. Nairobi, Kenya: ACTS press

[21] Mulder, M. B., and Coppolillo, P. (2015). Conservation: linking ecology, economics, and culture. Princeton University Press.

[22] Murphree, M. W. (2012). Protected areas and the commons. Common Property Resource Digest.

[23] Nelson, F. and A. Agrawal. (2008). Patronage or participation? Community-based natural resource management reform in Sub-Saharan Africa. Development and Change

[24] Nivola, C. A. (2008). Planting the trees of Kenya: The story of Wangari Maathai. Farrar Straus and Giroux.

[25] Noe, C., and Kangalawe, R. Y. (2015). Wildlife protection, community participation in conservation, and (dis) empowerment in southern Tanzania. Conservation and Society, 13(3)

[26] Ntuli, H., and Muchapondwa, E. (2015). The Role of Institutions in Community Wildlife Conservation in Zimbabwe. World Academy of Science, Engineering and Technology, International Journal of Environmental and Ecological Engineering, 2(2).

[27] Ormsby, A. A., and Bhagwat, S. A. (2010). Sacred forests of India: a strong tradition of community-based natural resource management. Environmental Conservation, 37(3).

[28] ORTPN, (2005). Strategic plan 2005-2008 ORTPN, Kigali-Rwanda, pp 26- 178

[29] Otto, J., Zerner, C., Robinson, J., Donovan, R., Lavelle, M., Villarreal, R., ... and Pearl, M. (2013). Natural connections: perspectives in community-based conservation. Island Press.

[30] Plumptre, A. J. and Williamson, E.A. (2011). Conservation-oriented research in the Virunga region. In Mountain Gorillas: Three decades of research at Karisoke. ed by M.M. Robbins, P. Sicotte and K. J. Stewart, pp. 361-389. University Press, Cambridge.

[31] Robinson, L. W., and Sasu, K. A. (2013). The role of values in a community-based conservation initiative in northern Ghana. Environmental Values, 22(5).

[32] Ruiz-Mallén, I., Schunko, C., Corbera, E., Rös, M., and Reyes-García, V. (2015). Meanings, drivers, and motivations for community-based conservation in Latin America.

[33] Rutagarama, E., Martin, A., Gray, M., Asuna, S., Bana, M., Basabose, A. and Mwine, M.(2008). A report on the experience of community conservation enterprises undertaken by the International Gorilla Conservation Programme

[34] Salafsky, N., and Wollenberg, E. (2010). Linking livelihoods and conservation: a conceptual framework and scale for assessing the integration of human needs and biodiversity.World development, 28(8).

[35] Schwartzman, S., and Zimmerman, B. (2015). Conservation alliances with indigenous peoples of the Amazon. Conservation Biology, 19(3).

[36] Seixas, C. S., and Davy, B. (2008). Self-organisation in integrated conservation and development initiatives. International Journal of the Commons, 2(1).

[37] Shrestha, U. (2013). Community participation in wetland conservation in Nepal. Journal of Agriculture and Environment.

[38] Shukla, S. R., and Sinclair, A. J. (2010). Strategies for self-organisation: learning from a village-level community-based conservation initiative in India. Human Ecology, 38(2).

[39] Souto, T., Deichmann, J. L., Núñez, C., and Alonso, A. (2014). Classifying conservation targets based on the origin of motivation: implications over the success of community-based conservation projects. Biodiversity and conservation, $23(5$.

[40] Tangui, J. K. (2014). The Role of Community Based Organisations in The Conservation Of The Environment In Kenya. A Case Of Kapcherop Division, Elgeyo Marakwet County.

[41] Toledo, V. M., Ortiz-Espejel, B., Cortés, L., Moguel, P., and Ordoñez, M. D. J. (2013). The multiple use of tropical forests by indigenous peoples in Mexico: a case of adaptive management. Conservation Ecology,7(3).

Citation: Dr. Isaboke Peter Kennedy Nyataya. "Community Based Organisations in Environment Conservation Endeavours in Rwanda " International Journal of Research in Sociology and Anthropology (IJRSA), vol 5, no. 1, 2019, pp. 1-11. doi:http://dx.doi.org/10.20431/2454-8677.0501001.

Copyright: () 2019 Authors. This is an open-access article distributed under the terms of the Creative Commons Attribution License, which permits unrestricted use, distribution, and reproduction in any medium, provided the original author and source are credited. 